\title{
Two New closo- or nido- Carborane Diphosphine Complexes: Synthesis, Characterization and Crystal Structures
}

\author{
Lingqian Kong, ${ }^{\dagger, \star}$ Daopeng Zhang,,${ }^{\S} *$ Fangfang Su, ${ }^{\star}$ Dacheng Li, ${ }^{\star}$ and Jianmin Dou ${ }^{\ddagger}, *$ \\ †Dongchang College, Liaocheng University, Liaocheng 252059, PR China \\ *School of Chemistry and Chemical Engineering, Liaocheng University, Liaocheng 252059, PR China. *E-mail: jmdou@lcu.edu.cn \\ ${ }^{\S}$ College of Chemical Engineering, Shandong University of Technology, Zibo 255049, PR China. *E-mail: dpzhang73@126.com \\ Received April 2, 2011, Accepted May 19, 2011
}

\begin{abstract}
Two new carborane complexes containing closo- or nido- carborane diphosphine ligands with the formula: complex $\left[\mathrm{Hg}\left(7,8-\left(\mathrm{PPh}_{2}\right)_{2}-7,8-\mathrm{C}_{2} \mathrm{~B}_{9} \mathrm{H}_{10}\right)_{2}\right] \mathrm{CH}_{2} \mathrm{Cl}_{2}(\mathbf{1})$ and $\left[\mathrm{Ag}_{2}(\mu-\mathrm{Cl})_{2}\left(1,2-\left(\mathrm{P}^{\mathrm{i}} \mathrm{Pr}_{2}\right)_{2}-1,2-\mathrm{C}_{2} \mathrm{~B}_{10} \mathrm{H}_{10}\right)_{2}\right]$ (2) have been synthesized and characterized by elemental analysis, ${ }^{1} \mathrm{H}$ and ${ }^{13} \mathrm{C}$ NMR spectroscopy and X-ray structure determination. The $\mathrm{X}$-ray structure analyses revealed that the carborane diphosphine ligand was degraded from closo-1,2- $\left(\mathrm{PPh}_{2}\right)_{2}-1,2-\mathrm{C}_{2} \mathrm{~B}_{10} \mathrm{H}_{10}$ to nido-[7,8-( $\left.\left(\mathrm{PPh}_{2}\right)_{2}-7,8-\mathrm{C}_{2} \mathrm{~B}_{9} \mathrm{H}_{10}\right]^{-}$in complex $\mathbf{1}$, while the closo nature of the starting ligand 1,2-( $\left(\mathrm{P}^{\mathrm{i}} \mathrm{Pr}_{2}\right)_{2}-1,2-\mathrm{C}_{2} \mathrm{~B}_{10} \mathrm{H}_{10}$ was retained in complex 2 . In either of the two complexes, the carborane diphosphine ligand was coordinated bidentately to the $\mathrm{Hg}(\mathrm{II})$ or $\mathrm{Ag}(\mathrm{I})$ center through its two phosphorus atoms, therefore forming a five-member cheating ring between the carborane ligand and the metal center. The coordination geometry of the metal atom is distorted tetrahedron formed by $\mathrm{P}_{4}$ unit in complex 1 and $\mathrm{P}_{2} \mathrm{Cl}_{2}$ unit in complex 2 , respectively.
\end{abstract}

Key Words : Synthesis and crystal structure, $\mathrm{Hg}(\mathrm{II})$ and $\mathrm{Ag}(\mathrm{I})$ complexes, $\left[7,8-\left(\mathrm{PPh}_{2}\right)_{2}-7,8-\mathrm{C}_{2} \mathrm{~B}_{9} \mathrm{H}_{10}\right]^{-}, 1,2-$ $\left(\mathrm{P}^{\mathrm{i}} \mathrm{Pr}_{2}\right)_{2}-1,2-\mathrm{C}_{2} \mathrm{~B}_{10} \mathrm{H}_{10}$

\section{Introduction}

Bidentate ligands have played an important role in the development of catalytic applications of metal organic complexes. ${ }^{1}$ One of the important fundamentals for these catalysts is that two cis positions of the metal center are available to perform the reaction, and bidentate phosphines have already been demonstrated to be very convenient for this sort of catalysis. ${ }^{2}$ The $o$-carborane diphosphine derivative 1,2-bis(phenylphosphanyl)-1,2-dicarba-closo-dodecaborane was first reported by Alexander and Schroeder in 1963. ${ }^{3}$ Because the two phosphorus atoms bonded to the two adjacent carbon atoms of the $o$-carborane are fixed by the geometry of the carborane skeleton in an eclipsed conformation at cis positions, stable complexes can be formed through a five-member chelating ring between the ligand and a metal atom, making these types of diphosphine ligands being widely studied in coordination chemistry.

The reactions of the closo ligand 1,2- $\left(\mathrm{PPh}_{2}\right)_{2}-1,2-\mathrm{C}_{2} \mathrm{~B}_{10} \mathrm{H}_{10}$ with transition metal compounds have been intensely studied, ${ }^{4-11}$ and the results reported previously showed that the polarity of the solvent used in the reactions played an very important role in the degradation process of the closo carborane diphosphine ligand. Recently, our group have also interested in carborane diphosphine ligands and reported some complexes containing closo carborane diphosphine 1,2- $\left(\mathrm{PPh}_{2}\right)_{2}-1,2-\mathrm{C}_{2} \mathrm{~B}_{10} \mathrm{H}_{10}, \quad 1,2-\left(\mathrm{P}^{\mathrm{i}} \mathrm{Pr}_{2}\right)_{2}-1,2-\mathrm{C}_{2} \mathrm{~B}_{10} \mathrm{H}_{10}$ and nido carborane diphosphine $\left[7,8-\left(\mathrm{PPh}_{2}\right)_{2}-7,8-\mathrm{C}_{2} \mathrm{~B}_{9} \mathrm{H}_{10}\right]^{-} ;{ }^{12,13}$ in which the $\mathrm{CuI}$ complex of 1,2-( $\left(\mathrm{PPh}_{2}\right)_{2}-1,2-\mathrm{C}_{2} \mathrm{~B}_{10} \mathrm{H}_{10}$ show some catalytic activity for the amination of iodobenzene with aniline. ${ }^{12 \mathrm{a}}$ Very recently, with the consideration that the
$\mathrm{Hg}$ complex of carborane organophosphorus-substituents ligands is still very rare, ${ }^{14}$ we investigated the reactions of 1,2- $\left(\mathrm{PPh}_{2}\right)_{2}-1,2-\mathrm{C}_{2} \mathrm{~B}_{10} \mathrm{H}_{10}$ with mercury(II) compounds. ${ }^{15}$ Here, we present one $\mathrm{Hg}$ complex $\left[\mathrm{Hg}\left(7,8-\left(\mathrm{PPh}_{2}\right)_{2}-7,8-\right.\right.$ $\left.\left.\mathrm{C}_{2} \mathrm{~B}_{9} \mathrm{H}_{10}\right)_{2}\right] \mathrm{CH}_{2} \mathrm{Cl}_{2}(\mathbf{1})$ and one silver(I) complex $\left[\mathrm{Ag}_{2}(\mu-\right.$ $\left.\mathrm{Cl})_{2}\left(1,2-\left(\mathrm{P}^{\mathrm{i}} \mathrm{Pr}_{2}\right)_{2}-1,2-\mathrm{C}_{2} \mathrm{~B}_{10} \mathrm{H}_{10}\right)_{2}\right]$ (2) based on two closo carborane diphosphine ligands $\left(1,2-\left(\mathrm{PPh}_{2}\right)_{2}-1,2-\mathrm{C}_{2} \mathrm{~B}_{10} \mathrm{H}_{10}\right.$ and 1,2-( $\left.\left(\mathrm{P}^{\mathrm{i}} \mathrm{Pr}_{2}\right)_{2}-1,2-\mathrm{C}_{2} \mathrm{~B}_{10} \mathrm{H}_{10}\right)$ with different steric effects, for which the synthesis, characterization and crystal structures will be described in this paper.

\section{Experimental}

Materials and Methods. All the reactions were carried out under an atmosphere of dry oxygen-free dinitrogen. Dichloromethane, ethanol, and $n$-hexane were dried with appropriate drying agents and distilled under dinitrogen prior to use. 1,2- $\left(\mathrm{PPh}_{2}\right)_{2}-1,2-\mathrm{C}_{2} \mathrm{~B}_{10} \mathrm{H}_{10}$ and 1,2-( $\left(\mathrm{P}^{\mathrm{i}} \mathrm{Pr}_{2}\right)_{2}-1,2-$ $\mathrm{C}_{2} \mathrm{~B}_{10} \mathrm{H}_{10}$ were synthesized according to a literature procedure. ${ }^{3,16}$ All chemicals were purchased and used as received. Infrared spectra was measured on a Nicolet-460 FT-IR spectrometer in the range $400-4000 \mathrm{~cm}^{-1}$ as $\mathrm{KBr}$ pellets. Elemental analysis $(\mathrm{C}, \mathrm{H})$ was performed with a PerkinElemer 2400 II Elemental Analyzer.

Synthesis.

[Hg(7,8-( $\left.\left.\mathbf{P P h})_{2}-\mathbf{7 , 8}-\mathbf{C}_{2} \mathbf{B}_{9} \mathbf{H}_{10}\right)_{2}\right] \mathbf{C H}_{2} \mathbf{C l}_{2}(\mathbf{1}): 1,2-\left(\mathrm{PPh}_{2}\right)_{2}-$ $1,2-\mathrm{C}_{2} \mathrm{~B}_{10} \mathrm{H}_{10}(102.4 \mathrm{mg}, 0.2 \mathrm{mmol})$ and $\mathrm{HgCl}_{2}(27.1 \mathrm{mg}, 0.1$ mmol) was mixed in $10 \mathrm{~mL} \mathrm{CH}_{3} \mathrm{CN}$. The mixture was refluxed for $5 \mathrm{~h}$ under the protection of $\mathrm{N}_{2}$, and then the colorless solid formed was filtrated off and dried in vacuum (71.2 mg, 55.2\%). The crystal suitable for X-ray diffraction 
was obtained from a dichloromethane- $n$-hexane solution. FT-IR iKBr $\left(\mathrm{cm}^{-1}\right): 2958 \mathrm{~s}, 2578 \mathrm{~m}, 1611 \mathrm{~s}, 1437 \mathrm{~m}, 1095 \mathrm{~m}$, $748 \mathrm{~m}, 685 \mathrm{~s}, 493 \mathrm{~m} .{ }^{1} \mathrm{H} \mathrm{NMR}\left(400.15 \mathrm{MHz}, \mathrm{CDCl}_{3}\right): \delta$ 7.192-7.897 ppm (40H);-2.10 ppm (2H, B-H-B); ${ }^{13} \mathrm{C}$ NMR $\left(100.62 \mathrm{MHz}, \mathrm{CDCl}_{3}\right) \delta$ 128.6-135.9 ppm (48C), $\delta$ 76.178.5 ppm (4C). Anal. calc. for $\mathrm{C}_{53} \mathrm{H}_{62} \mathrm{~B}_{18} \mathrm{Cl}_{2} \mathrm{HgP}_{4}$ : C, 49.38; H, 4.85. Found: C, 49.30; H, 4.77\%.

[Ag $\left.\mathbf{A g}_{\mathbf{2}}(\boldsymbol{\mu}-\mathbf{C l})_{\mathbf{2}}\left(\mathbf{1 , 2}-\left(\mathbf{P}^{\mathrm{i}} \mathbf{P r}_{2}\right)_{2}-\mathbf{1}, \mathbf{2}-\mathbf{C}_{\mathbf{2}} \mathbf{B}_{\mathbf{1 0}} \mathbf{H}_{10}\right)_{2}\right]$ (2): $\mathrm{AgCl}(14.4$ $\mathrm{mg}, 0.1 \mathrm{mmol})$ was added into a solution of 1,2-( $\left.\mathrm{P}^{\mathrm{i}} \mathrm{Pr}_{2}\right)_{2}-1,2-$ $\mathrm{C}_{2} \mathrm{~B}_{10} \mathrm{H}_{10}$ (51. mg, $\left.0.1 \mathrm{mmol}\right)$ in $\mathrm{CH}_{2} \mathrm{Cl}_{2}(10 \mathrm{~mL})$. The mixture was refluxed for $5 \mathrm{~h}$ under the protection by $\mathrm{N}_{2}$, and concentrated to $5 \mathrm{~mL}$, and then $20 \mathrm{~mL} n$-hexane was added to precipitate the solid. Yield: $58.5 \mathrm{mg}, 56.3 \%$. The crystal suitable for X-ray diffraction was grown from a dichloromethanen-hexane solution. FT-IR $v \mathrm{KBr}\left(\mathrm{cm}^{-1}\right)$ : $2999 \mathrm{~m}$, $2961 \mathrm{~s}, 2921 \mathrm{~m}, 2873 \mathrm{~m}, 2851 \mathrm{~m}, 2577 \mathrm{~s}, 1631 \mathrm{~m}, 1460 \mathrm{~s}, 1386 \mathrm{~m}$, 1099m, 701m. ${ }^{1} \mathrm{H} \mathrm{NMR}\left(400.15 \mathrm{MHz}, \mathrm{CDCl}_{3}\right): \delta 1.64-1.67$ ppm $\left(\mathrm{CH}_{3}, 48 \mathrm{H}\right), 2.71 \mathrm{ppm}(\mathrm{CH}, 8 \mathrm{H}),{ }^{13} \mathrm{C}$ NMR $(100.63$ $\mathrm{MHz}, \mathrm{CDCl}_{3}$ ): $\delta 21.0 \mathrm{ppm}$ (16C), 30.8 (8C) $76.7 \mathrm{ppm}(4 \mathrm{C})$. Anal. Calc. for $\mathrm{C}_{28} \mathrm{H}_{76} \mathrm{Ag}_{2} \mathrm{~B}_{20} \mathrm{Cl}_{2} \mathrm{P}_{4}$ : C, 32.35; H, 7.37. Found: C, 32.44; H, 7.48\%.

Crystallography. The colorless crystals of complexes $\mathbf{1}$ and 2 were selected for the diffraction analysis. The collections of intensity data were carried out on a Bruker Smart-1000 CCD diffractometer, using graphite-monochromatized Mo-K $\alpha$ radiation $(\lambda=0.71073 \AA$ ) at $298(2) \mathrm{K}$. The structures were solved by direct methods and expanded using Fourier difference techniques with SHELXTL-97 program package. ${ }^{17}$ The non-hydrogen atoms were refined anisotropically by full-matrix least-squares calculations on $\mathrm{F}^{2}$. All $\mathrm{H}$ atoms were located from Fourier maps and were refined isotropically. The crystallographic data for the two complexes were summarized in Table 1 and the selected bond lengths and angles of complexes $\mathbf{1}$ and $\mathbf{2}$ were shown in Table 2.

The CIF tables of $\mathbf{1}$ and $\mathbf{2}$ have been deposited at the Cambridge Crystallographic Data Centre with the deposition numbers CCDC 891541 and 891542, respectively. Copies of the data can be obtained free of charge on application to CCDC, 12 Union Road, Cambridge CB2 1EZ, UK [fax: (+44) 1223 336033; email: deposit@ccdc.cam.ac.uk or www: http://www.ccdc.cam.ac.uk.

Table 1. Details of the crystal parameters, data collections and refinements for complexes $\mathbf{1}$ and $\mathbf{2}$.

\section{Results and Discussion}

Synthesis and IR Spectrum. The partial degradation of the closo diphosphine ligand 1,2-( $\left.\mathrm{PPh}_{2}\right)_{2}-1,2-\mathrm{C}_{2} \mathrm{~B}_{10} \mathrm{H}_{10}$ by metal complex driven has been first disclosed by Teixidor's group, ${ }^{6}$ and based on this method, many neutral complexes of the nido-[7,8-( $\left.\left(\mathrm{PPh}_{2}\right)_{2}-7,8-\mathrm{C}_{2} \mathrm{~B}_{9} \mathrm{H}_{10}\right]^{-}$with the similar formula $\left[\mathrm{M}\left\{7,8-\left(\mathrm{PPh}_{2}\right)_{2}-7,8-\mathrm{C}_{2} \mathrm{~B}_{9} \mathrm{H}_{10}\right\}\left(\mathrm{PPh}_{3}\right)\right](\mathrm{M}=\mathrm{Cu}, \mathrm{Ag}$, $\mathrm{Au})$ have been obtained by the reactions of transition metal complexes with the closo ligand in ethanol under the reflux conditions. All the results above indicated that the solvent used could play an important role in the degradation process.
Table 1. Details of the crystal parameters, data collections and refinements for complexes $\mathbf{1}$ and $\mathbf{2}$

\begin{tabular}{|c|c|c|}
\hline & 1 & 2 \\
\hline Empirical formula & $\mathrm{C}_{53} \mathrm{H}_{62} \mathrm{~B}_{18} \mathrm{Cl}_{2} \mathrm{HgP}_{4}$ & $\mathrm{C}_{28} \mathrm{H}_{76} \mathrm{Ag}_{2} \mathrm{~B}_{20} \mathrm{Cl}_{2} \mathrm{P}_{4}$ \\
\hline Formula weight & 1288.98 & 1039.61 \\
\hline Crystal system & Monoclinic & Monoclinic \\
\hline Space group & $P 2(1) / n$ & $C 2 / m$ \\
\hline$a(\AA)$ & $15.842(3)$ & $24.578(6)$ \\
\hline$b(\AA)$ & $22.591(3)$ & $14.745(4)$ \\
\hline$c(\AA)$ & $19.162(2)$ & $7.874(2)$ \\
\hline$\alpha\left({ }^{\circ}\right)$ & 90 & 90 \\
\hline$\beta\left({ }^{\circ}\right)$ & $100.030(3)$ & $91.231(3)$ \\
\hline$\gamma\left(\left(^{\circ}\right)\right.$ & 90 & 90 \\
\hline$V\left(\AA^{3}\right)$ & $6752.7(16)$ & $2853.0(12)$ \\
\hline$Z$ & 4 & 2 \\
\hline$D\left(\mathrm{Mg} \mathrm{m}^{-3}\right)$ & 1.268 & 1.210 \\
\hline$F(000)$ & 2576 & 1064 \\
\hline Goodness-of-fit on $F^{2}$ & 0.994 & 1.009 \\
\hline $\begin{array}{l}\text { Final } R \text { indices } \\
{[I>2 \operatorname{sigma}(I)]}\end{array}$ & $\begin{array}{c}R_{1}=0.0699 \\
\mathrm{w} R_{2}=0.1725\end{array}$ & $\begin{array}{c}R_{1}=0.0388 \\
\mathrm{w} R_{2}=0.1687\end{array}$ \\
\hline$R$ indices (all data) & $\begin{array}{c}R_{1}=0.1425 \\
\mathrm{w} R_{2}=0.2278\end{array}$ & $\begin{array}{c}R_{1}=0.0484 \\
\mathrm{w} R_{2}=0.1842\end{array}$ \\
\hline
\end{tabular}

The strong polarity solvent can make the closo skeleton of the carborane cage be degraded to nido form, while the closo skeleton can be retained when weak polarity solvent was used in the reaction. Based on these results, we investigated the reactions of 1,2-( $\left.\mathrm{PPh}_{2}\right)_{2}-1,2-\mathrm{C}_{2} \mathrm{~B}_{10} \mathrm{H}_{10} \mathrm{HgCl}_{2}$ in $\mathrm{CH}_{3} \mathrm{CN}$ and 1,2-( $\left.\mathrm{P}{ }^{\mathrm{P}} \mathrm{Pr}\right)_{2}-1,2-\mathrm{C}_{2} \mathrm{~B}_{10} \mathrm{H}_{10}$ with $\mathrm{AgCl}$ in $\mathrm{CH}_{2} \mathrm{Cl}_{2}$ under the reflux condition, respectively, and obtained two complexes containing closo- or nido- carborane diphosphine ligands with the formula $\left[\mathrm{Hg}\left(7,8-\left(\mathrm{PPh}_{2}\right)_{2}-7,8-\mathrm{C}_{2} \mathrm{~B}_{9} \mathrm{H}_{10}\right)_{2}\right] \cdot \mathrm{CH}_{2} \mathrm{Cl}_{2}$ (1) and $\left[\mathrm{Ag}_{2}(\mu-\mathrm{Cl})_{2}\left(1,2-\left(\mathrm{P}^{\mathrm{i}} \mathrm{Pr}_{2}\right)_{2}-1,2-\mathrm{C}_{2} \mathrm{~B}_{10} \mathrm{H}_{10}\right)_{2}\right](2)$ (Scheme 1).

Both of the two complexes have been characterized by FT-IR, ${ }^{1} \mathrm{H}$ and ${ }^{13} \mathrm{C}$ NMR spectroscopy. The IR spectra of these two complexes were very similar to each other. The absorption at 2958 (1) and $2999(2) \mathrm{cm}^{-1}$ may be attributed to the $v_{\mathrm{C}-\mathrm{H}}$ stretching vibration of benzene ring and isopropyl group, and the characteristic absorptions of terminal B-H vibrations are at about $2570 \mathrm{~cm}^{-1}$ for $\mathbf{1}$ and 2, which drop in the normal range from 2625 to $2450 \mathrm{~cm}^{-1}$. ${ }^{18}$ The peak at about $1100 \mathrm{~cm}^{-1}$ is the absorption of $v_{\mathrm{C} \text { (carborane cage)-P, which }}$ is lightly shifted in keeping with phosphorus coordination to the 1,2- $\mathrm{C}_{2} \mathrm{~B}_{10} \mathrm{H}_{10}$ moiety. The ${ }^{1} \mathrm{H}$ NMR (400.15 MHz) showed a resonance at $c a .-2.10 \mathrm{ppm}$ which can be assigned to the bridge $\mathrm{H}$ atoms of $\mathrm{B}-\mathrm{H}-\mathrm{B}$ in complex 1 . The resonance at about $130 \mathrm{ppm}, 21-30 \mathrm{ppm}$ and about $77 \mathrm{ppm}$ in the ${ }^{13} \mathrm{C}$ NMR spectra $(100.63 \mathrm{MHz})$ for these two complexes can be assigned to the carbon atom of the benzene ring, the isopropyl group and the carborane cage, respectively.

Description of the Structure. Crystal structures of these two complexes are shown in Figures 1 and 2, respectively. Selected bonds and angles are given in Table 2. Complex 1 contains four formula units in the unit cell and the solvent $\mathrm{CH}_{2} \mathrm{Cl}_{2}$, and crystallizes in the monoclinic space group 

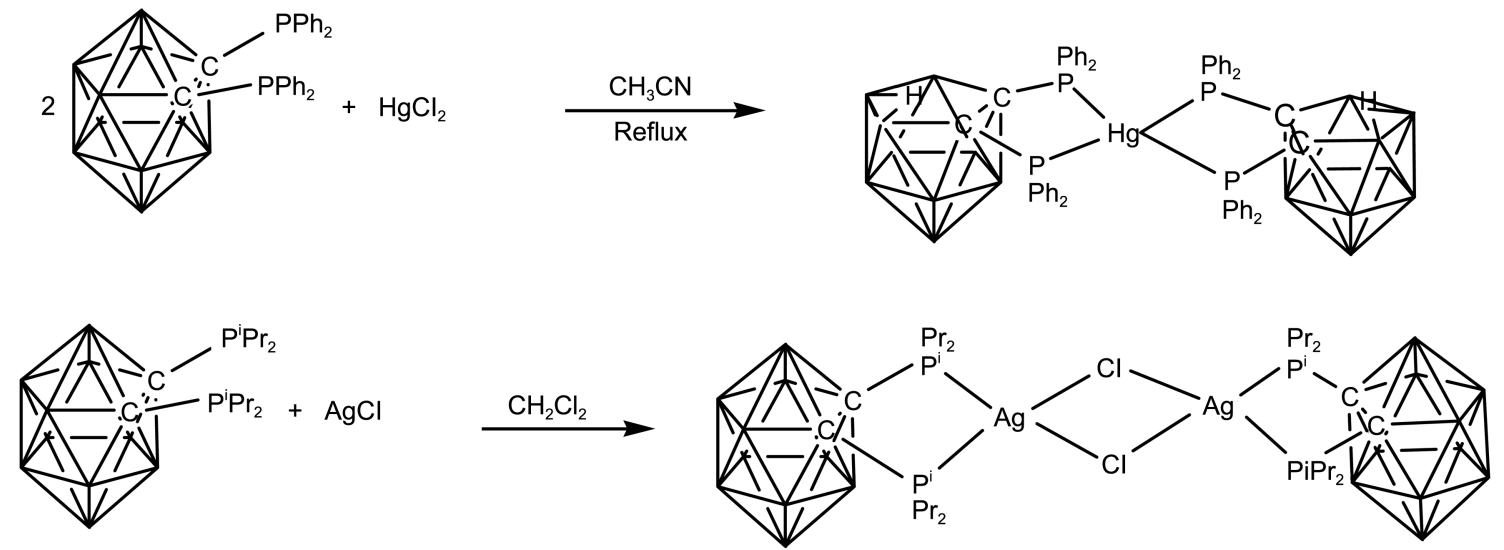

Scheme 1. The synthesis of complexes $\mathbf{1}$ and 2.

$P 2(1) / n$. The central $\mathrm{Hg}$ atom is coordinated to four $\mathrm{P}$ atoms coming from two nido carborane diphosphine anions [7,8$\left.\left(\mathrm{PPh}_{2}\right)_{2}-7,8-\mathrm{C}_{2} \mathrm{~B}_{9} \mathrm{H}_{10}\right]^{-}$. The geometry at the $\mathrm{Hg}$ atom is a distorted tetrahedron, and the angles around $\mathrm{Hg}$ (Table 2) deviate much from the values for a regular tetrahedron coordination mode. The distances of the four $\mathrm{Hg}-\mathrm{P}$ bonds are almost equal to each other, and the average value of $2.575 \AA$ is slightly longer than those in the reported $\mathrm{Hg}$ complex $\left[\mathrm{HgCl}\left(\mathrm{PPh}_{3}\right)\left\{7,8-\left(\mathrm{PPh}_{2}\right)_{2}-7,8-\mathrm{C}_{2} \mathrm{~B}_{9} \mathrm{H}_{10}\right\}\right],{ }^{15}$ which can be attributed to the steric effect of the two ligands. The angles of $\mathrm{P}(1)-\mathrm{Hg}(1)-\mathrm{P}(2)$ (79.63(8)) and $\mathrm{P}(3)-\mathrm{Hg}(1)-\mathrm{P}(4)(78.19(9)$ ) are slightly smaller than the value of $82.74(5)$ in $\left[\mathrm{HgCl}\left(\mathrm{PPh}_{3}\right)\left\{7,8-\left(\mathrm{PPh}_{2}\right)_{2}-7,8-\mathrm{C}_{2} \mathrm{~B}_{9} \mathrm{H}_{10}\right\}\right]$. As for the other parameters in complex $\mathbf{1}$, such as the distances of $\mathrm{P}-\mathrm{Cc}$ and $\mathrm{Cc}-\mathrm{Cc}$ as listed in Table 2, no noticeable differences have been found on comparison to those in the above complex.

The complex 2 crystallizes in the monoclinic $C 2 / m$ space group (Fig. 2) and contains two formula units in the unit cell. It is composed of two same units $\left[\operatorname{Ag}\left(1,2-\left(\mathrm{P}^{\mathrm{i}} \mathrm{Pr}_{2}\right)_{2}-1,2-\right.\right.$ $\left.\mathrm{C}_{2} \mathrm{~B}_{10} \mathrm{H}_{10}\right)$ ] bridged by two $\mathrm{Cl}$ atoms. The $\mathrm{Ag}$ atom is coordinated by two $\mathrm{P}$ atoms of the $\mathrm{P}^{\mathrm{i}} \mathrm{Pr}_{2}$ group and two $\mathrm{Cl}$ anions to

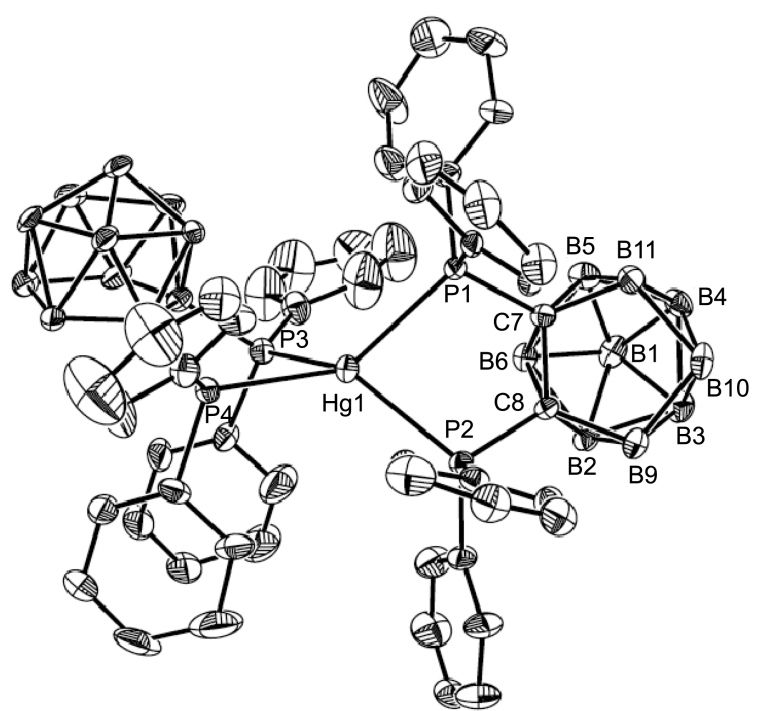

Figure 1. The crystal structure of complex 1. All the $\mathrm{H}$ atoms and the solvent $\mathrm{CH}_{2} \mathrm{Cl}_{2}$ were omitted for clarity. complete the distorted tetrahedral configuration, which can be proved by the bond angles around the Ag atom (Table 2). The Ag1-P1 and Ag1-Cl1 distances are 2.4717(12) and 2.6220(19) $\AA$, respectively, which are basically consistent with the corresponding bond lengths in $\mathrm{Ag}_{2}(\mu-\mathrm{Cl})_{2}(1,2-$ $\left.\left.\left(\mathrm{PPh}_{2}\right)_{2}-1,2-\mathrm{C}_{2} \mathrm{~B}_{10} \mathrm{H}_{10}\right)_{2}\right] .{ }^{19}$ The dihedral angle between the planes through the atom groups P1-Ag1- P1\#1 and C11-Ag1Cl1\#1 is $86.85^{\circ}$, indicating that these two planes are almost perpendicular each other. The $\mathrm{C}(1)-\mathrm{C}(2)$ bond distance in complex 2 is $1.69(2) \AA$, which are slightly shorter than 1.720 $\AA$ in the free ligand. ${ }^{16}$ Comparison of the configuration of the closo carborane diphosphine ligand in complex 2 with that in the free 1,2-( $\left(\mathrm{P}^{\mathrm{i}} \mathrm{Pr}_{2}\right)_{2}-1,2-\mathrm{C}_{2} \mathrm{~B}_{10} \mathrm{H}_{10}$ ligand reveals differences. In the free ligand the $\mathrm{P}(1)-\mathrm{C}(1)-\mathrm{C}(2)-\mathrm{P}(2)$ torsion angle is $10.6(3)^{\mathrm{o}}{ }^{16}$ while this angle in complex 4 is only $0.1(5){ }^{\circ} \mathrm{C}$. This data indicates that coordination of the ligand to $\operatorname{Ag}(\mathrm{I})$ alters the symmetry of the ligand, making the symmetry of the ligand in the complex 2 closely approach $C_{2 v}$.

Symmetry transformations used to generate equivalent atoms:

$$
\# 1: \mathrm{x},-\mathrm{y}, \mathrm{z} \# 2:-\mathrm{x}+1,-\mathrm{y},-\mathrm{z}+1
$$

In summary, we have obtained two new carborane diphosphine complexes containing closo or nido diphosphine ligand by using two types of closo carborane diphosphine

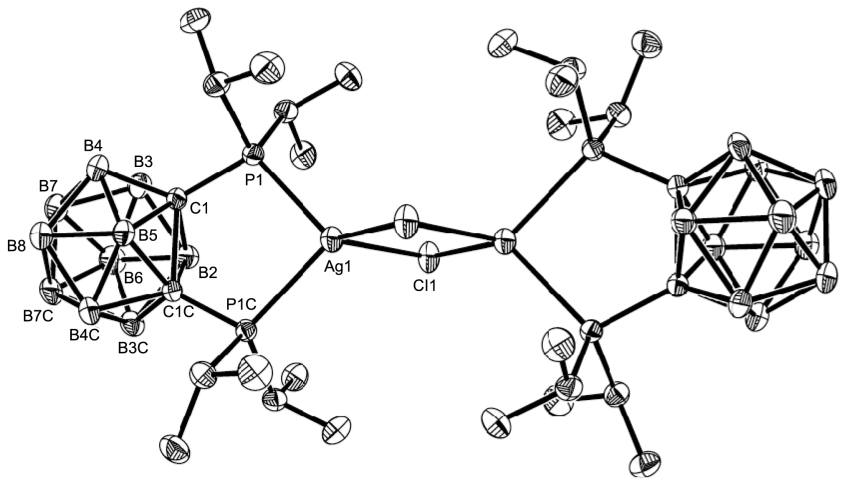

Figure 2. The crystal structure of complex 2. All the $\mathrm{H}$ atoms were omitted for clarity. 
Table 2. Selected bond lengths $(\AA)$ and angles $\left({ }^{\circ}\right)$ for complexes 1 and 2

\begin{tabular}{llll}
\hline \multicolumn{1}{c}{$\mathbf{1}$} & \multicolumn{2}{c}{$\mathbf{2}$} \\
\hline $\mathrm{Hg}(1)-\mathrm{P}(1)$ & $2.580(3)$ & $\mathrm{Hg}(1)-\mathrm{P}(1)$ & $2.4717(12)$ \\
$\mathrm{Hg}(1)-\mathrm{P}(2)$ & $2.552(3)$ & $\mathrm{Hg}(1)-\mathrm{Cl}(1)$ & $2.6220(19)$ \\
$\mathrm{Hg}(2)-\mathrm{P}(3)$ & $2.585(3)$ & $\mathrm{P}(1)-\mathrm{C}(1)$ & $1.870(5)$ \\
$\mathrm{Hg}(2)-\mathrm{P}(4)$ & $2.581(3)$ & $\mathrm{C}(1)-\mathrm{C}(2)$ & $1.692(2)$ \\
$\mathrm{P}(1)-\mathrm{C}(7)$ & $1.821(10)$ & & \\
$\mathrm{P}(2)-\mathrm{C}(8)$ & $1.839(10)$ & & \\
$\mathrm{C}(7)-\mathrm{C}(8)$ & $1.593(13)$ & & \\
& & & \\
$\mathrm{P}(1)-\mathrm{Hg}(1)-\mathrm{P}(2)$ & $79.63(8)$ & $\mathrm{P}(1) \# 1-\mathrm{Ag}(1)-\mathrm{P}(1)$ & $91.93(6)$ \\
$\mathrm{P}(3)-\mathrm{Hg}(2)-\mathrm{P}(4)$ & $78.19(9)$ & $\mathrm{P}(1) \# 1-\mathrm{Ag}(1)-\mathrm{Cl}(1) \# 2$ & $122.87(4)$ \\
$\mathrm{P}(1)-\mathrm{Hg}(1)-\mathrm{P}(3)$ & $122.27(9)$ & $\mathrm{P}(1)-\mathrm{Ag}(1)-\mathrm{Cl}(1) \# 2$ & $122.87(4)$ \\
$\mathrm{P}(1)-\mathrm{Hg}(1)-\mathrm{P}(4)$ & $129.70(9)$ & $\mathrm{P}(1) \# 1-\mathrm{Ag}(1)-\mathrm{Cl}(1)$ & $111.05(4)$ \\
$\mathrm{P}(2)-\mathrm{Hg}(1)-\mathrm{P}(3)$ & $133.40(9)$ & $\mathrm{P}(1)-\mathrm{Ag}(1)-\mathrm{Cl}(1)$ & $111.05(4)$ \\
$\mathrm{P}(2)-\mathrm{Hg}(1)-\mathrm{P}(4)$ & $121.53(9)$ & $\mathrm{Cl}(1) \# 2-\mathrm{Ag}(1)-\mathrm{Cl}(1)$ & $97.56(6)$ \\
\hline
\end{tabular}

ligands with different steric effects in different polar solvent, in which the closo carborane skeleton was degraded to nido form in complex $\mathbf{1}$ and that was retained in complex $\mathbf{2}$. The present result can further confirm the fact that the polarity of the solvent has obvious influence on the structure of the complexes formed, despite of the different steric effect brought by the carborane diphosphine ligand.

Acknowledgments. This work was supported by the National Natural Science Foundation of P. R. China (project no. 20971063, 20371025), Natural Science Foundation of Shandong Province (Y2007B01) and Shandong Tai-Shan Scholar Research Found.

\section{References}

1. Van Leeuwen, P. W. N. M.; Kamer, P. C. J.; Reek, J. N. H.; Dierkes, P. Chem. Rev. 2000, 100, 2741.

2. Kim, J. S.; Pawlow, J. H.; Wojcinski II, L. M.; Murtuza, S.; Kacker, S.; Sen, A. J. Am. Chem. Soc. 1998, 120, 1932.

3. Alexander, R. P.; Schroeder, H. Inorg. Chem. 1963, 2, 1107.

4. (a) Paavola, S.; Teixidor, F.; Viñas, C.; Kivekäs, R. J. Organomet. Chem. 2002, 657, 187. (b) Brunner, H.; Apfebacher, A.; Zabel, M. Eur. J. Inorg. Chem. 2001, 917. (c) Paavola, S.; Teixidor, F.; Viñas, C.; Kivekäs, R. J. Organomet. Chem. 2002, 645, 39. (d) Sundberg, M. R.; Paavola, S.; Viñas, C.; Teixidor, F.; Uggla, R.; Kivekäs, R.
Inorg. Chim. Acta 2005, 358, 2107.

5. Paavola, S.; Teixidor, F.; Viñas, C.; Kivekäs, R. Acta Crystallogr. Sect. C 2002, C58, m237.

6. Teixidor, F.; Viñas, C.; Abad, M. M.; Lopez, M.; Casabo, J. Organometallics 1993, 12, 3766.

7. (a) Bembenek, E.; Crespo, O.; Gimeno, M. C.; Jones, P. G.; Laguna, A. Chem. Ber. 1994, 127, 835. (b) Crespo, O.; Gimeno, M. C.; Jones, P. G.; Laguna, A. J. Chem. Soc. Dalton Trans. 1996, 4583.

8. (a) Calhorda, M. J.; Crespo, O.; Gimeno, M. C.; Jones, P. G.; Laguna, A.; López-de-Luzuriaga, J. M.; Perez, J. L.; Ramón, M. A.; Veios, L. F. Inorg. Chem. 2000, 39, 4280. (b) Crespo, O.; Gimeno, M. C.; Jones, P. G.; Laguna, A.; López-de-Luzuriaga, J. M.; Monge, M.; Pérez, J. L.; M. Ramón, A. Inorg. Chem. 2003, 42, 2061. (c) Effendy, P. C.; Healy, C. L.; Noack, C. L.; Skelton, B. W.; White, A. H.; Young, D. J. Z. Anorg. Allg. Chem. 2007, 633, 2689.

9. Adams, J. J.; Negro, A. S. D.; Arulsamy, N.; Sullivan, B. P. Inorg. Chem. 2008, 47, 1871.

10. Teixidor, F.; Viñas, C.; Abad, M. M.; Whitaker, C.; Rius, J. Organometallics 1996, 15, 3154.

11. Balema, V. P.; Somoza, F.; Hey-Hawkins, E. Eur. J. Inorg. Chem. 1998, 651 .

12. (a) Zhang, D. P.; Dou, J. M.; Gong, S. W.; Li, D. C.; Wang, D. Q. Appl. Organomet. Chem. 2006, 20, 632. (b) Zhang, D. P.; Dou, J. M.; Li, D. C.; Wang, D. Q. Inorg. Chim. Acta 2006, 359, 4243. (c) Dou, J. M.; Zhang, D. P.; Li, D. C.; Wang, D. Q. J. Organomet. Chem. 2006, 691, 5673. (d) Dou, J. M.; Zhang, D. P.; Li, D. C.; Wang, D. Q. Inorg. Chem. Commun. 2006, 9, 1099. (e) Dou, J. M.; Zhang, D. P.; Li, D. C.; Wang, D. Q. Eur. J. Inorg. Chem. 2007, 53. (f) Dou, J. M.; Zhang, D. P.; Zhu, Y. H.; Li, D. C.; Wang, D. Q. Inorg. Chim. Acta 2007, 360, 3387. (g) Dou, J. M.; Zhang, D. P.; Li, D. C.; Wang, D. Q. Polyhedron 2007, 26, 719. (h) Dou, J. M.; Zhang, D. P.; Zhu, Y. H.; Li, D. C.; Wang, D. Q. Polyhedron 2007, 26, 4216.

13. Dou, J. M.; Su, F. F.; Nie, Y.; Li, D. C.; Wang, D. Q. Dalton Trans. 2008, 4152.

14. Su, F. F.; Guo, Q. L.; Dou, J. M.; Li, D. C.; Wang, D. Q. Acta Cryst. 2008, E64, m134.

15. Kong, L. Q.; Zhang, D. P.; Su, F. F.; Lu, J.; Li, D. C.; Dou, J. M. Inorg. Chim. Acta. Accepted.

16. Kivekas, R.; Teixidor F.; Vinas, C.; Acta Crystallogr. Sect. C 1995, 51, 1868.

17. Sheldrick, G. M. SHELXTL 5.10 for Windows NT: Structure Determination Software Programs, Bruker Analytical X-ray Systems, Madison, WI, 1997.

18. Kazuo, N. Infrared and Raman Spectra of Inorganic and Coordination Compounds; Translated by Huang, D. R., Wang, R. Q., Chemical Industry Press: Beijing, 1986; p 175.

19. Zhang, D. P.; Dou, J. M.; Li, D. C.; Wang, D. Q. Acta Cryst. 2007, E63, m1086. 